\title{
Commercial production of crops irrigated with gypsiferous mine water
}

\author{
NZ Jovanovic ${ }^{1}$, JG Annandale ${ }^{1 *}$, AS Claassens ${ }^{1}$, SA Lorentz ${ }^{2}$, PD Tanner ${ }^{3}$, ME Aken ${ }^{4}$ and FDI Hodgson ${ }^{5}$ \\ ${ }^{1}$ Dept. Plant Production and Soil Science, University of Pretoria, Pretoria 0001, South Africa \\ 2 School of Bioresources Engineering and Environmental Hydrology, University of Natal, Private Bag X01, Scottsville 3209, South Africa \\ ${ }^{3}$ Anglo Base Metals, 55 Marshall Street, Johannesburg 2107, South Africa \\ ${ }^{4}$ Anglo Coal Environmental Services, Private Bag X9, Leraatsfontein 1038, South Africa \\ ${ }^{5}$ Institute for Groundwater Studies, University of the Free State, Bloemfontein 9300, South Africa
}

\begin{abstract}
The use of gypsiferous mine water for irrigation of agricultural crops is a promising technology that could add value through agricultural production and utilise mine effluent. Crop response to irrigation with gypsiferous mine water, as well as the impact on soil and groundwater resources were investigated in a three-year field trial set up at Kleinkopje Colliery (Witbank, Mpumalanga Province, South Africa). Sugar-beans, maize and wheat were irrigated with four centre pivots on virgin and rehabilitated land, under three irrigation management regimes using two qualities of mine water. Good crop yields were obtained compared to dry-land cropping. Waterlogging in certain areas of the fields indicated that especially rehabilitated land should be properly prepared and, where necessary, waterways built to prevent yield reduction. Soil salinity increased over the duration of the trial due to high concentrations of $\mathrm{Ca}^{2+}, \mathrm{SO}_{4}^{2-}$ and $\mathrm{Mg}^{2+}$ in the irrigation water, but this never reached levels critical to yields of most crops. Exchangeable $\mathrm{Ca}^{2+}$ and $\mathrm{Mg}^{2+}$ in the soil increased with time, whilst $\mathrm{K}^{+}$decreased. Plant analyses indicated possible nutrient deficiencies, which should be easily managed through corrective fertilisation. The groundwater impact was limited based on borehole measurements, indicating the presence of a buffer zone between the cropped soil profile and groundwater, but this should be monitored over a longer period. Commercial production of crops under irrigation with gypsiferous mine water is feasible and the resulting environmental impact is limited, but further research is required to confirm these findings over a longer period.
\end{abstract}

\section{Introduction}

The mining industry is one of the most important endeavours in South Africa, both from the point of view of gross national product and job creation. In the mining of mineral resources, pollution problems are created with adverse effects on the already scarce water resources. Disposal of mine wastewater is a world-wide problem occurring wherever operating coal- and gold-mines, as well as closed underground and open-cast workings are found (Pulles et al., 1995). The type of water emanating from mines depends largely on the geological properties of the coal, gold ore and other geological material with which waters come into contact. The concentrations of salts and other constituents frequently render such waters unsuitable for direct discharge to the river systems except in periods of high rainfall when an adequate dilution capacity is present and controlled release is permitted. Current measures to prevent pollution of the environment were reviewed by Pulles et al. (1996).

Gypsiferous mine water can be regarded either as one of mining's greatest problems, or as a potential asset. Large amounts of wastewater could possibly be made available to the farming community and utilised for the irrigation of highly productive soils in the coal-fields of the Mpumalanga Province in South Africa, where water resources for irrigation are already under extreme pressure. In this summer rainfall region, dry-land winter cropping is not feasible and mine water is often the only source of water for irrigation. Moreover, concentrating the gypsiferous soil solution

\footnotetext{
* To whom all correspondence should be addressed.

푱 012 420-3223; fax 012 420-4120; e-mail: jannanda@postino.up.ac.za Received 7 December 2001; accepted in revised form 25 June 2002.
}

through evapotranspiration, thereby precipitating gypsum in the soil profile, will reduce environmental pollution as these salts are removed from the water system. Contamination of downstream water supplies for other users could therefore be reduced, and additional income could be achieved through farming. The high capital expense and operational cost of effluent treatment by mines could also be offset to some extent by farming income. Aluminium toxicity, often occurring in these soils, could be reduced through irrigation with gypsiferous mine water (Barnard et al., 1998). A surplus water problem for the coal-mining industry could also be significantly reduced, as the irrigation option (mine-water utilisation during dry spells) could complement the controlled release into river systems during rainy spells.

The potential for use of gypsiferous mine water for crop irrigation was first evaluated in South Africa by Du Plessis (1983). In previous work, Barnard et al. (1998) carried out field and laboratory screening trials, where a wide range of crop and pasture species were irrigated with lime-treated acid mine drainage. They proved that irrigation with this water should not present a soil salinity or crop production problem within a relatively short time period of three years, provided careful fertilisation management was applied (Jovanovic et al., 1998). The long-term effect, 50 years of irrigation with gypsiferous water on soil and water resources was assessed by Annandale et al. (1999a), using the Soil Water Balance (SWB) model (Annandale et al., 1999b) in combination with the CLIMGEN weather data generator (Campbell, 1990). They simulated the long-term soil-water and salt balance, and concluded that irrigation with gypsiferous mine water should not cause irreparable damage to soil and groundwater resources.

In this study, the general objective was to evaluate the environmental sustainability of irrigation with gypsiferous mine water under commercial crop production at Kleinkopje Colliery 


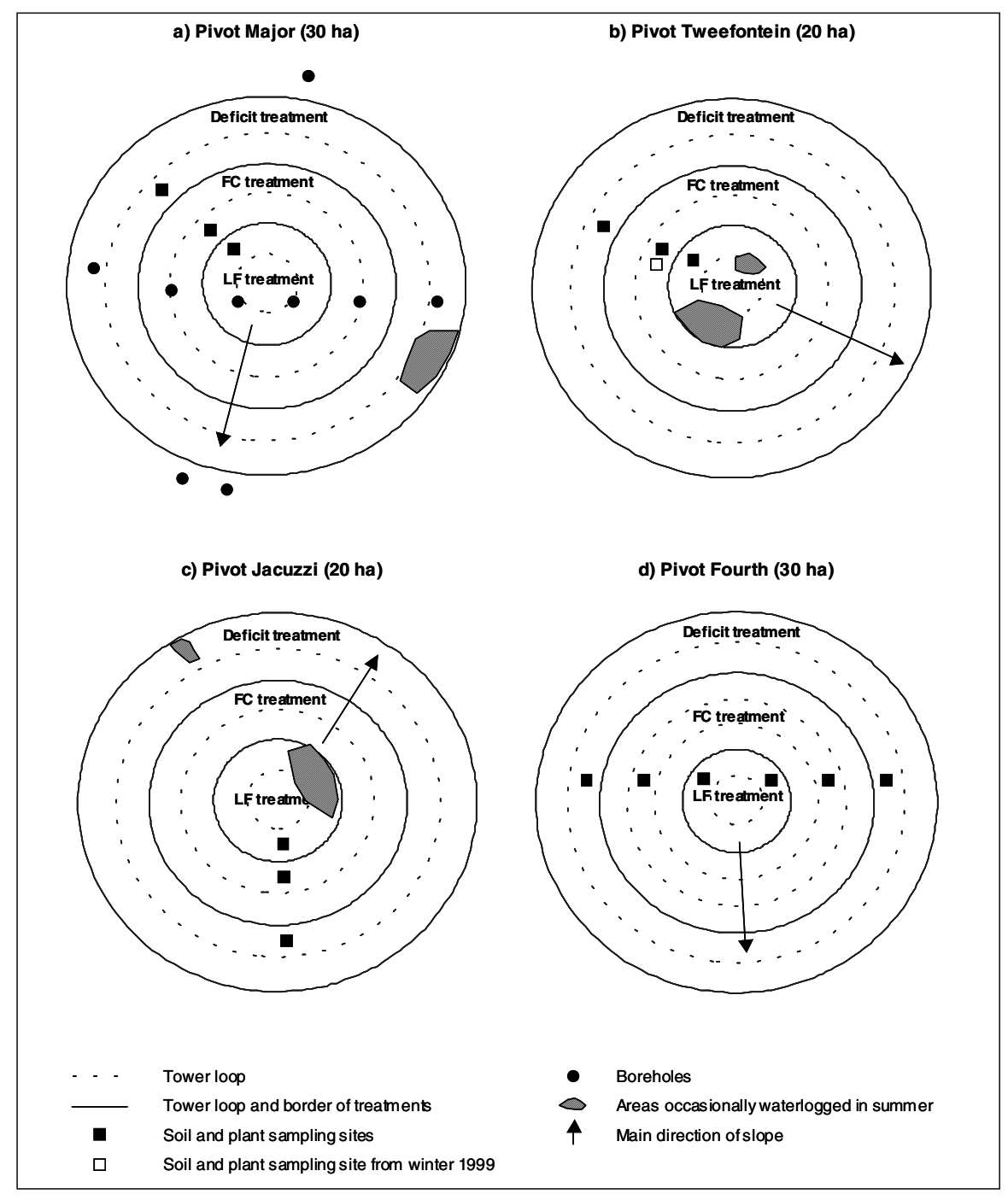

Figure 1

Experimental layout of irrigation pivots. $F C=$ Field capacity; $L F=$ Leaching fraction
Tweefontein Pan.

Four centre pivots were used for irrigation with gypsiferous mine water during the course of the trial. Pivot Major irrigated 30 ha of unmined soil, predominantly Clovelly and Bainsvlei forms (Soil Classification Working Group, 1991), and used Jacuzzi water for irrigation. Pivot Tweefontein irrigated 20 ha of rehabilitated mined soil and used water from the Tweefontein Pan for irrigation. Pivot Jacuzzi irrigated 20 ha of rehabilitated soil from 1997 to 1999 and used Jacuzzi water for irrigation. In autumn 1999, pivot Jacuzzi was moved to an unmined site, due to problematic drainage at the rehabilitated site, and from then on, it was referred to as pivot Fourth. One tower and an extension were added to the pivot, so that pivot Fourth irrigated 30 ha of virgin Hutton soil (Soil Classification Working Group, 1991) and used Tweefontein water for irrigation.

At pivot Major, free percolation of water was limited by an underlying layer of weathered sandstone with some plinthic formations (generally between 0.5 and $1.1 \mathrm{~m}$ depth), and at pivots Jacuzzi and Tweefontein by the spoil layer on rehabilitated land (generally at 0.9 m depth). In winter 1998 , contours and waterways were built in order to facilitate drainage of excess surface water from the cultivated fields at pivots Major, Jacuzzi and Tweefontein. The soil at pivot Fourth was well drained with a high infiltration capacity, and as the field has little slope, no runoff measures were required. near Witbank in the Mpumalanga Province. The specific objectives were:

- to determine crop response to irrigation with two types of mine water;

- to determine the impact of irrigation with inferior quality water on unmined and rehabilitated mined soil; and

- to investigate the extent of groundwater contamination.

\section{Materials and methods}

A field trial was established at Kleinkopje Colliery ( $26^{\circ} 00^{\prime} \mathrm{S}, 29^{\circ} 21^{\prime}$ $\mathrm{E}$; altitude $1570 \mathrm{~m}$ ). The climate is that of summer rainfall with an average annual precipitation of about $700 \mathrm{~mm}$. The trial lasted from the 1997/98 summer season until the 2000 winter season.

Irrigations were carried out using two water sources. "Jacuzzi" water is pumped from old underground workings and needs to be utilised by Kleinkopje Colliery in order to continue mining. Most of this water is pumped to a large storage dam and is released under controlled conditions under licence from the South African Department of Water Affairs and Forestry in Pretoria. "Tweefontein" water is pumped from an active open-cast pit and stored in the
The highest bulk densities were found in the consolidated spoil materials of the rehabilitated profiles (from $1760 \mathrm{~kg} \cdot \mathrm{m}^{-3}$ to 2048 $\mathrm{kg} \cdot \mathrm{m}^{-3}$ for Tweefontein and Jacuzzi fields). The top soil layers in both the unmined and rehabilitated mined profiles had bulk densities marginally suitable for crop production (between $1600 \mathrm{~kg} \cdot \mathrm{m}^{-3}$ and $1760 \mathrm{~kg} \cdot \mathrm{m}^{-3}$ ). The bulk densities of the layers below the rooting zone in the unmined profiles were typically lower than the densities found in the spoil layers of the rehabilitated profiles (approximately $1600 \mathrm{~kg} \cdot \mathrm{m}^{-3}$ at pivot Fourth and $1800 \mathrm{~kg} \cdot \mathrm{m}^{-3}$ at pivot Major).

The nozzle packages of the pivots were chosen to provide three application rates of irrigation water:

- irrigations up to field capacity (FC treatment);

- irrigations with a leaching fraction applied (LF treatment, with water applications $120 \%$ of the FC treatment); and

- irrigations below field capacity (deficit or "room for rain" treatment, with water applications $80 \%$ of the FC treatment).

The experimental layout of the pivot fields is shown in Fig. 1. From winter 1999, the differential nozzle package of pivot Tweefontein was replaced to apply uniform irrigations up to field capacity along its radius. This limited waterlogging and crop losses, which were 
experienced in some areas in the previous summer cropping seasons (Fig. 1b)

Irrigations were scheduled to refill the soil profile to field capacity in the FC treatment, based on neutron water meter measurements. Irrigation and rainfall were recorded with tipping bucket rain gauges (Texas Instruments) connected to CR10X data loggers (Campbell Scientific Inc., Logan Utah, USA) at each pivot and treatment. Irrigation water samples were collected at regular intervals and analysed by Kleinkopje Colliery.

Sugar-beans (Phaseolus vulgaris), maize (Zea mays) and wheat (Triticum aestivum) were grown during the course of the trial. The cultivars used are reported in Table 1. Agronomic techniques commonly adopted in the area were applied by two farming companies (Amfarms, Ogies and Smith Bros., Witbank). These were reported in detail by Annandale et al. (2001). At the end of each cropping season, three replicates of plant material from $1 \mathrm{~m}^{2}$ ground area were sampled at each pivot and treatment. No replications of plant samples were taken at pivots Jacuzzi and Tweefontein for the summer 1998/99 sugar-beans crop due to logistical problems. Sampling was done at sites where healthygrowing plants occurred, representative of the largest area of the fields (Fig. 1). From winter 1999, sampling at pivot Tweefontein was done at one site, representing the FC treatment (Fig. 1b). At pivot Fourth, sampling was done at two sites in each treatment, along a diameter transect (Fig. 1d). In the first four seasons, yields were determined by drying the harvestable plant part in an oven at $60^{\circ} \mathrm{C}$ for $3 \mathrm{~d}$. Yields were expressed as dry matter of pods, ears or cobs, as this was measured for crop growth modelling purposes. In the last two seasons, yields were expressed as air-dry grain yields. During the critical stages for crop growth, whole-plant samples were taken at all pivot sites and analysed in the laboratory for $\mathrm{N}, \mathrm{P}$, $\mathrm{K}, \mathrm{Ca}, \mathrm{Mg}, \mathrm{Na}, \mathrm{SO}_{4}, \mathrm{Cu}, \mathrm{Fe}, \mathrm{Mn}, \mathrm{Zn}, \mathrm{B}$ and $\mathrm{Mo}$, in order to identify and correct possible nutritional deficiencies through fertilisation. Sampling was done close to the areas where plant samples were taken for yield measurement (Fig. 1).

Soil samples were collected from the soil profiles of each pivot and treatment area at the start of the trial and at the end of each cropping season. Sampling was done close to the areas where plant samples were taken for yield determination (Fig. 1). The following parameters were determined for $0.2 \mathrm{~m}$ soil layers down to $1 \mathrm{~m}$ : $\mathrm{pH}\left(\mathrm{H}_{2} \mathrm{O}\right)$, electrical conductivity of the saturated soil extract, Bray I P, concentrations of soluble $\mathrm{Ca}^{2+}, \mathrm{Mg}^{2+}, \mathrm{K}^{+}, \mathrm{Na}^{+}, \mathrm{NH}_{4}^{+}, \mathrm{SO}_{4}^{2-}, \mathrm{Cl}^{-}$ $, \mathrm{NO}_{3}^{-}, \mathrm{HCO}_{3}^{-}$and $\mathrm{CO}_{3}^{2-}$, as well as concentrations of exchangeable $\mathrm{Ca}^{2+}, \mathrm{Mg}^{2+}, \mathrm{K}^{+}$and $\mathrm{Na}^{+}$. These data were essential to determine the impact of irrigation with gypsiferous mine water on soil chemical properties and for fertilisation recommendations.

Deep-soil sampling was carried out in June 2000. This was done in order to explore whether any salt breakthrough originating from irrigation could be identified below the root-zone. Deep-soil samples were collected from pivots Major, Fourth and Tweefontein, close to the areas where soil and plant sampling occurred (Fig. 1). A geological drill rig fitted with a $100 \mathrm{~mm}$ diameter push-tube soil corer was used to obtain complete cores in each of the irrigation treatment areas, and in an area just outside each of the three pivots, the latter samples being intended to represent soil not exposed to irrigation with gypsiferous mine water. Each soil core was divided in 200 to $300 \mathrm{~mm}$ long subsamples and bagged. The samples were air-dried and analysed in the laboratory.

Nine boreholes were drilled at pivot Major in order to investigate the extent of groundwater contamination. The positions of the boreholes are reported in Fig. 1a. The surface slope through the irrigation area is to the South-West at an average gradient of 1:30. Borehole 1 was intended to monitor virgin conditions, but it collapsed soon after installation. Boreholes 2 to 7 were spaced on a West to East transect, approximately coinciding with the $1560 \mathrm{~m}$ contour across the irrigation area. Boreholes 8 and 9 were located at the lowest part of the field. The holes were all drilled to a depth of $15 \mathrm{~m}$. This shallow depth was necessitated by the presence of underground mining, which could be as shallow as $20 \mathrm{~m}$ below the surface in some places. Drilling of the boreholes was done through air percussion drilling. The hole diameters were $165 \mathrm{~mm}$. Piezometers consisting of a slotted PVC tube $(62.5 \mathrm{~mm}$ in diameter $)$ were installed in the boreholes for the purpose of measuring groundwater levels and water sampling. The piezometer casing also served to keep the holes from collapsing and to effectively seal the holes in the vertical dimension, thus preventing surface water from flowing into the holes. Groundwater samples were collected at regular intervals and analysed in the laboratory for $\mathrm{Al}, \mathrm{Ba}, \mathrm{B}, \mathrm{Br}$, $\mathrm{Ca}, \mathrm{Cl}, \mathrm{Cr}, \mathrm{Cu}, \mathrm{Fe}, \mathrm{Fl}, \mathrm{Li}, \mathrm{Mg}, \mathrm{Mn}, \mathrm{Mo}, \mathrm{Ni}, \mathrm{NO}_{2}, \mathrm{NO}_{3}, \mathrm{P}, \mathrm{K}, \mathrm{Se}, \mathrm{Na}$, $\mathrm{Sr}, \mathrm{SO}_{4}, \mathrm{~V}, \mathrm{Zn}, \mathrm{pH}$, electrical conductivity (EC) and total alkalinity. Great care was taken to ensure that groundwater was not unduly contaminated during the installations. A certain degree of contamination was, however, unavoidable, since sodium bentonite was one of the prime materials used to hydraulically isolate one horizon from another. Periodic flushing was carried out for three months after piezometer installation to ensure that all free salts from the bentonite were leached. The results from chemical analyses during this period were therefore ignored, since they did not reflect the true composition of the groundwater.

\section{Results and discussion}

\section{Irrigation water quality}

Irrigation water quality analyses are summarised in Table 2 . The data are the time average of 48 samples for Jacuzzi and 17 samples for Tweefontein water. The analyses indicated that the two waters were similar with high concentrations of $\mathrm{Ca}^{2+}$ and $\mathrm{SO}_{4}^{2-}$, and relatively high concentrations of $\mathrm{Mg}^{2+}$. The concentrations of other ions were inside the range recommended by the Department of Water Affairs and Forestry (1993) for agricultural use. The \pm 1 standard errors of the measurements indicated that seasonal fluctuations in irrigation water salinity were generally measured. The concentrations of $\mathrm{Mn}^{2+}$ in Jacuzzi water were $<10 \mathrm{mg} \cdot \ell^{-1}$, except for the period between 22/07/1998 and 26/08/1998 when concentrations of between 15.5 and $52.7 \mathrm{mg} \cdot \ell^{-1}$ were measured. This increased the average concentration to above $10 \mathrm{mg} \cdot \ell^{-1}$, which is the upper range recommended by the Department of Water Affairs and Forestry (1993) for irrigation use on neutral and alkaline fine-textured soils for periods up to 20 years, and caused a large standard error. Two unusually high values measured for $\mathrm{Fe}^{2+}$ concentration $\left(60 \mathrm{mg} \cdot \ell^{-1}\right.$ on $03 / 06 / 1998$ and $81.8 \mathrm{mg} \cdot \ell^{-1}$ on $05 / 10$ / 1999) pushed up the average concentration and standard error.

\section{Crop response}

Seasonal irrigation and rainfall, as well as harvestable dry matter production for each pivot and treatment, are summarised in Table 1. More irrigation water was applied during the dry winter seasons, when rainfall was low. It is evident that the differentiation of water treatments was generally successful depending on seasonal rainfall. Although comparable yield data with good quality water are not available, the yield of sugar-beans obtained under irrigation with mine water at pivot Major $\left(3.23 \mathrm{Mg} \cdot \mathrm{ha}^{-1}\right)$ was comparable to yields registered in the area, and definitely higher than under dryland conditions (1.12 Mg.ha- ${ }^{-1}$ ) (Table 1). Yields of sugar-beans on 


\begin{tabular}{|c|c|c|c|c|c|c|}
\hline \multicolumn{7}{|c|}{$\begin{array}{l}\text { TABLE 1 } \\
\text { Irrigation, rainfall and measured yield for each crop, pivot and treatment }\end{array}$} \\
\hline Season & Pivot & Crop & Treatment & $\begin{array}{l}\text { Irrigation } \\
(\mathrm{mm})\end{array}$ & $\begin{array}{c}\text { Rainfall } \\
(\mathrm{mm})\end{array}$ & $\begin{array}{c}\text { Yield } \\
\left(\text { Mg.ha-1) }^{-1}\right.\end{array}$ \\
\hline \multirow[t]{3}{*}{ Summer 1997/98 } & Major & Sugar-beans (cv. Pan 148 and Kranskop) & $\begin{array}{l}\text { Leaching fraction } \\
\text { Field capacity } \\
\text { Deficit } \\
\text { Dry-land }\end{array}$ & $\begin{array}{c}113 \\
82 \\
74 \\
0\end{array}$ & $\begin{array}{l}345 \\
338 \\
336 \\
321\end{array}$ & $\begin{array}{l}3.23 \pm 0.24^{1} \\
\pm 0.31^{1} \\
2.61 \pm 0.25^{1} \\
1.12 \pm 0.10^{1}\end{array}$ \\
\hline & Tweefontein & Sugar-beans (cv. Kranskop) & $\begin{array}{l}\text { Leaching fraction } \\
\text { Field capacity } \\
\text { Deficit }\end{array}$ & $\begin{array}{l}82 \\
70 \\
59\end{array}$ & $\begin{array}{l}192 \\
191 \\
194\end{array}$ & $\begin{array}{l}1.26 \pm 0.48^{1} \\
1.14 \pm 0.33^{1} \\
1.12 \pm 0.17^{1}\end{array}$ \\
\hline & Jacuzzi & Sugar-beans (cv. Kranskop) & $\begin{array}{l}\text { Leaching fraction } \\
\text { Field capacity } \\
\text { Deficit }\end{array}$ & $\begin{array}{l}49 \\
41 \\
29\end{array}$ & $\begin{array}{l}190 \\
198 \\
199\end{array}$ & $\begin{array}{l}1.37 \pm 0.32^{1} \\
0.58 \pm 0.15^{1} \\
0.55 \pm 0.20^{1}\end{array}$ \\
\hline \multirow[t]{3}{*}{ Winter 1998} & Major & Wheat (cv. SST 825 and Kariega 103) & $\begin{array}{l}\text { Leaching fraction } \\
\text { Field capacity } \\
\text { Deficit }\end{array}$ & $\begin{array}{l}419 \\
329 \\
224\end{array}$ & $\begin{array}{l}234 \\
226 \\
221\end{array}$ & $\begin{array}{l}5.04 \pm 0.21^{2} \\
5.28 \pm 0.62^{2} \\
4.43 \pm 0.40^{2}\end{array}$ \\
\hline & Tweefontein & Wheat(cv. SST 825 and Kariega 103) & $\begin{array}{l}\text { Leaching fraction } \\
\text { Field capacity } \\
\text { Deficit }\end{array}$ & $\begin{array}{l}444 \\
339 \\
208\end{array}$ & $\begin{array}{l}184 \\
222 \\
201\end{array}$ & $\begin{array}{l}4.98 \pm 0.12^{2} \\
5.14 \pm 0.32^{2} \\
3.75 \pm 0.49^{2}\end{array}$ \\
\hline & Jacuzzi & Wheat(cv. SST 825 and Kariega 103) & $\begin{array}{l}\text { Leaching fraction } \\
\text { Field capacity } \\
\text { Deficit }\end{array}$ & $\begin{array}{l}408 \\
368 \\
315\end{array}$ & $\begin{array}{l}202 \\
202 \\
207\end{array}$ & $\begin{array}{l}5.17 \pm 0.06^{2} \\
4.11 \pm 0.55^{2} \\
3.92 \pm 0.13^{2}\end{array}$ \\
\hline \multirow[t]{3}{*}{ Summer 1998/99 } & Major & Maize(short-season,cv. not available) & $\begin{array}{l}\text { Leaching fraction } \\
\text { Field capacity } \\
\text { Deficit }\end{array}$ & $\begin{array}{l}341 \\
264 \\
198\end{array}$ & $\begin{array}{l}204 \\
205 \\
190\end{array}$ & $\begin{array}{l}7.83 \pm 1.66^{3} \\
7.17 \pm 0.43^{3} \\
3.77 \pm 0.50^{3}\end{array}$ \\
\hline & Tweefontein & Sugar-beans (cv. Kranskop) & $\begin{array}{l}\text { Leaching fraction } \\
\text { Field capacity } \\
\text { Deficit }\end{array}$ & $\begin{array}{l}278 \\
237 \\
199\end{array}$ & $\begin{array}{l}161 \\
154 \\
156\end{array}$ & $\begin{array}{l}1.37^{1} \\
1.09^{1} \\
1.05^{1}\end{array}$ \\
\hline & Jacuzzi & Sugar-beans (cv. Kranskop) & $\begin{array}{l}\text { Leaching fraction } \\
\text { Field capacity } \\
\text { Deficit }\end{array}$ & $\begin{array}{l}428 \\
360 \\
275\end{array}$ & $\begin{array}{l}152 \\
152 \\
152\end{array}$ & $\begin{array}{l}1.23^{1} \\
0.77^{1} \\
0.53^{1}\end{array}$ \\
\hline \multirow[t]{3}{*}{ Winter 1999} & Major & Wheat (cv. SST 825) & $\begin{array}{l}\text { Leaching fraction } \\
\text { Field capacity } \\
\text { Deficit }\end{array}$ & $\begin{array}{l}309 \\
285 \\
197\end{array}$ & $\begin{array}{l}119 \\
119 \\
119\end{array}$ & $\begin{array}{l}6.40 \pm 1.12^{2} \\
6.19 \pm 1.05^{2} \\
4.70 \pm 0.35^{2}\end{array}$ \\
\hline & Fourth & Wheat(cv. SST 825 and SST 876) & $\begin{array}{l}\text { Leaching fraction (site 1) } \\
\text { Field capacity (site 1) } \\
\text { Deficit (site 1) } \\
\text { Leaching fraction (site 2) } \\
\text { Field capacity (site 2) } \\
\text { Deficit (site 2) }\end{array}$ & $\begin{array}{l}391 \\
295 \\
245 \\
446 \\
283 \\
265\end{array}$ & $\begin{array}{l}122 \\
114 \\
118 \\
119 \\
109 \\
115\end{array}$ & $\begin{array}{l}6.73 \pm 0.13^{2} \\
6.51 \pm 2.05^{2} \\
5.51 \pm 1.57^{2} \\
8.08 \pm 0.71^{2} \\
6.45 \pm 0.94^{2} \\
6.35 \pm 0.63^{2}\end{array}$ \\
\hline & Tweefontein & Wheat (cv. SST 825) & Field capacity & 458 & 132 & $6.34 \pm 0.67^{2}$ \\
\hline \multirow[t]{3}{*}{ Summer 1999/00 } & Major & Maize (PHI 33408 Bt gene) & $\begin{array}{l}\text { Leaching fraction } \\
\text { Field capacity } \\
\text { Deficit }\end{array}$ & $\begin{array}{l}77 \\
41 \\
31\end{array}$ & $\begin{array}{l}630 \\
621 \\
619\end{array}$ & $\begin{array}{l}4.04 \pm 0.39^{4} \\
4.22 \pm 0.96^{4} \\
4.14 \pm 0.47^{4}\end{array}$ \\
\hline & Fourth & Maize (PHI 33408 Bt gene) & $\begin{array}{l}\text { Leaching fraction (site 1) } \\
\text { Field capacity (site 1) } \\
\text { Deficit (site 1) } \\
\text { Leaching fraction (site 2) } \\
\text { Field capacity (site 2) } \\
\text { Deficit (site 2) }\end{array}$ & $\begin{array}{l}9 \\
9 \\
23 \\
45 \\
30 \\
23\end{array}$ & $\begin{array}{l}676 \\
643 \\
660 \\
667 \\
666 \\
660\end{array}$ & $\begin{array}{l}3.76 \pm 0.14^{4} \\
3.49 \pm 0.67^{4} \\
3.85 \pm 0.29^{4} \\
2.81 \pm 0.24^{4} \\
2.26 \pm 0.28^{4} \\
3.05 \pm 0.50^{4}\end{array}$ \\
\hline & Tweefontein & Maize (PHI 33408 Bt gene) & Field capacity & 13 & 668 & $3.51 \pm 0.74^{4}$ \\
\hline \multirow[t]{3}{*}{ Winter 2000} & Major & Wheat (cv. SST 825) & $\begin{array}{l}\text { Leaching fraction } \\
\text { Field capacity } \\
\text { Deficit }\end{array}$ & $\begin{array}{l}404 \\
354 \\
320\end{array}$ & $\begin{array}{l}2 \\
2 \\
2\end{array}$ & $\begin{array}{l}3.52 \pm 0.37^{4} \\
4.29 \pm 0.45^{4} \\
3.09 \pm 0.16^{4}\end{array}$ \\
\hline & Fourth & Wheat (cv. SST 825) & $\begin{array}{l}\text { Leaching fraction (site 1) } \\
\text { Field capacity (site 1) } \\
\text { Deficit (site 1) } \\
\text { Leaching fraction (site 2) } \\
\text { Field capacity (site 2) } \\
\text { Deficit (site 2) }\end{array}$ & $\begin{array}{l}525 \\
414 \\
314 \\
415 \\
450 \\
338\end{array}$ & $\begin{array}{l}2 \\
2 \\
2 \\
2 \\
2 \\
2\end{array}$ & $\begin{array}{l}\text { Loss to hail } \\
\text { Loss to hail } \\
\text { Loss to hail } \\
\text { Loss to hail } \\
\text { Loss to hail } \\
\text { Loss to hail }\end{array}$ \\
\hline & Tweefontein & Wheat (cv. SST 825) & Field capacity & 615 & 2 & Loss to hail \\
\hline
\end{tabular}


TABLE 2

Time average quality of two mine waters (Jacuzzi and Tweefontein) used at Kleinkopje colliery for irrigation (from December 1997 to October 1999)

\begin{tabular}{|l|c|c|}
\hline \multirow{2}{*}{ Analysis } & \multicolumn{2}{|c|}{ Water } \\
\cline { 2 - 3 } & Jacuzzi & Tweefontein \\
\hline $\mathrm{pH}$ & $6.5 \pm 0.5$ & $8.0 \pm 0.6$ \\
Electrical conductivity $\left(\mathrm{mS} \cdot \mathrm{m}^{-1}\right)$ & $284 \pm 33$ & $296 \pm 56$ \\
$\mathrm{Ca}^{2+}\left(\mathrm{mg} \cdot \ell^{-1}\right)$ & $494 \pm 73$ & $423 \pm 59$ \\
$\mathrm{Mg}^{2+}\left(\mathrm{mg} \cdot \ell^{-1}\right)$ & $188 \pm 51$ & $239 \pm 27$ \\
$\mathrm{Na}^{+}\left(\mathrm{mg} \cdot \ell^{-1}\right)$ & $41 \pm 12$ & $55 \pm 6$ \\
$\mathrm{~K}^{+}\left(\mathrm{mg} \cdot \ell^{-1}\right)$ & $10 \pm 3$ & $19 \pm 3$ \\
$\mathrm{Al}^{3+}\left(\mathrm{mg} \cdot \ell^{-1}\right)$ & $0.35 \pm 0.33$ & $0.02 \pm 0.04$ \\
$\mathrm{Fe}^{2+}\left(\mathrm{mg} \cdot \ell^{-1}\right)$ & $4.02 \pm 15.38$ & $0.07 \pm 0.11$ \\
$\mathrm{Mn}^{2+}\left(\mathrm{mg} \cdot \ell^{-1}\right)$ & $11.39 \pm 12.50$ & $0.14 \pm 0.14$ \\
$\mathrm{SO}_{4}^{2-}\left(\mathrm{mg} \cdot \ell^{-1}\right)$ & $1925 \pm 180$ & $1748 \pm 165$ \\
$\mathrm{Cl}^{-}\left(\mathrm{mg} \cdot \ell^{-1}\right)$ & $18 \pm 5$ & $42 \pm 13$ \\
$\mathrm{~F}^{-}\left(\mathrm{mg} \cdot \ell^{-1}\right)$ & $1.21 \pm 0.28$ & $0.97 \pm 0.10$ \\
$\mathrm{NO}_{3}^{-}\left(\mathrm{mg} \cdot \ell^{-1}\right)$ & $0.48 \pm 0.27$ & $0.27 \pm 0.33$ \\
$\mathrm{HCO}_{3}^{-}\left(\mathrm{mg} \cdot \ell^{-1}\right)$ & $142 \pm 9$ & $68 \pm 0$ \\
$\mathrm{TDS}^{\left(\mathrm{mg} \cdot \ell^{-1}\right)}$ & $2867 \pm 201$ & $2753 \pm 171$ \\
\hline
\end{tabular}

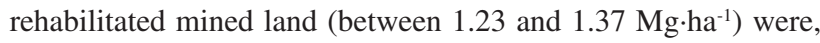
however, low compared to unmined land, likely due to late planting dates, soil compaction and high bulk densities, low soil $\mathrm{pH}$ and nutritional deficiencies. Pivot Jacuzzi also did not operate for a large part of the 1997/98 summer season due to mechanical and electrical problems resulting in the crop suffering severe water stress. There was also waterlogging in certain areas of the field (Fig. 1c). Hail damage also occurred at pivot Jacuzzi during the vegetative stage of the crop in the 1997/98 season. Yield reductions were also experienced due to waterlogging in certain areas at pivot Tweefontein (Fig. 1b). The yield of sugar-beans on rehabilitated mined land did not improve in the 1998/99 summer season compared to 1997/98, even after levelling works were carried out and waterways built to reduce waterlogging in certain areas of the fields. Sugar-beans were, therefore, replaced by maize during the 1999/00 season (Table 1).

Particular attention is required in managing irrigations on rehabilitated mined soil on top of compacted spoil with high bulk densities. The hydraulic conductivity of the spoil layer was generally at least one order of magnitude lower than that of the overlying soil (Annandale et al., 2001). The spoil layer restricted deep drainage of water and the leaching of salts from the overlying soil layers, and had significant ramifications with respect to waterlogging and the lateral flow process. Ponding occurred during the rainy summer season, probably due to subsurface lateral drainage from higher areas.

Excellent yields of wheat were obtained on both unmined and rehabilitated mined land (between 5.14 and $8.08 \mathrm{Mg} \cdot \mathrm{ha}^{-1}$ ) (Table 1). Wheat is reportedly more tolerant to soil salinity than beans (Maas, 1986). The yield of the short-season cultivar of maize was also good on virgin land (7.83 Mg.ha-1, pivot Major, 1998/99 season) (Table 1).

The maize crops were damaged in the beginning of the 1999/ 00 season, when an excess of herbicide (up to 3 times the planned rate) was mistakenly applied to all three pivots by the farming company. This resulted in yield losses (Table 1). The expected yields were between 6 and $10 \mathrm{Mg} \cdot$ ha $^{-1}$ for the short-season cultivar.
The high rainfall experienced during the cropping season also affected the crops by causing localised waterlogging. This was particularly evident in certain areas at Tweefontein pivot (rehabilitated land, Fig. 1b), but also occurred at pivot Major (Fig. 1a). The maize hybrid used in the short cropping season was chosen for the BT-gene, which is designed to limit insect damage. However, it appeared that this hybrid is very susceptible to Northern Leaf Blight (rust). This proved to be the case and extensive rust was noted on the crops near the end of the season. A neighbouring farmer had planted the same hybrid early in the season, which served as a source of infection. This was also a reason for the reduced yield obtained. Fungicide applications were required to control the spread of the disease within the pivots.

In October 2000, a hailstorm completely wiped out the wheat crops at pivots Fourth and Tweefontein (Table 1). The estimated crop loss at pivot Major was $40 \%$. The hailstorm occurred during the grain-filling stage of wheat. The potential yield at all three pivots was estimated to be $8 \mathrm{Mg} \cdot \mathrm{ha}^{-1}$.

No symptoms of foliar injury due to sprinkler irrigation with two gypsiferous waters of similar composition were noted for all crops. Visual observation and laboratory analyses of plant samples indicated that no specific symptoms of nutrient deficiency or toxicity occurred due to excess gypsum in the irrigation water, which showed that fertilisation was appropriate. The chemical analyses of plant material indicated that nutrient levels were generally normal and within the ranges recommended by Fageria et al. (1991), Plank (1989) and Katyal and Randhawa (1983). High $\mathrm{Ca}$ and $\mathrm{SO}_{4}$ contents were occasionally measured in plant material, as these were the dominant species in the irrigation water. High Fe, $\mathrm{Mn}$ and $\mathrm{Zn}$ levels were occasionally observed due to anaerobic conditions caused by periodic waterlogging, in particular on rehabilitated soils. The detailed results of plant nutrition analyses obtained in this trial were reported by Annandale et al. (2001).

\section{Soils}

Soil $\mathrm{pH}$ in the root-zone generally showed a slight increase during the course of the trial for all pivots (Fig. 2). The saturated soil EC and the soluble ions in the saturated soil extract fluctuated depending on seasonal irrigation and rainfall as well as on the irrigation and rainfall events prior to soil sampling. An example is shown in Fig. 3 for saturated soil EC measured in three treatments at pivot Major, which was irrigated throughout the duration of the field trial. Saturated soil EC showed a tendency to increase with time, but the values decreased in December 2000, as the 2000/01 summer season was extremely rainy (Table 1). Saturated soil EC was never $>400$ $\mathrm{mS} \cdot \mathrm{m}^{-1}$, even after particularly dry seasons. The data generally indicated higher soil salinity in the top soil layers compared to deeper layers, due to high frequency irrigation. Similar conclusions were drawn for the other three pivot sites.

Soluble $\mathrm{Ca}^{2+}, \mathrm{Mg}^{2+}$ and $\mathrm{SO}_{4}^{2-}$ generally showed a tendency to increase with time in the root-zone of all four pivot sites, due to the relatively high concentrations of these ions in irrigation water. Soluble $\mathrm{K}^{+}$did not show any particular trend and concentrations were lower than those of $\mathrm{Ca}^{2+}$ and $\mathrm{Mg}^{2+}$ by one order of magnitude, as the irrigation water had a low $\mathrm{K}^{+}$concentration. The concentrations of other ions in the soil solution were negligible. Exchangeable $\mathrm{Ca}^{2+}$ and $\mathrm{Mg}^{2+}$ increased with time, whilst $\mathrm{K}^{+}$decreased at all four pivot sites. This indicates that $\mathrm{Ca}^{2+}$ and, to a certain extent $\mathrm{Mg}^{2+}$, replaces $\mathrm{K}^{+}$on the cation-exchange complex. If loss of $\mathrm{K}^{+}$through leaching causes nutrient deficiencies to the crop, corrective fertilisation should be applied before symptoms appear. Field monitoring of crop nutrient status is therefore essential. Very low 
Major

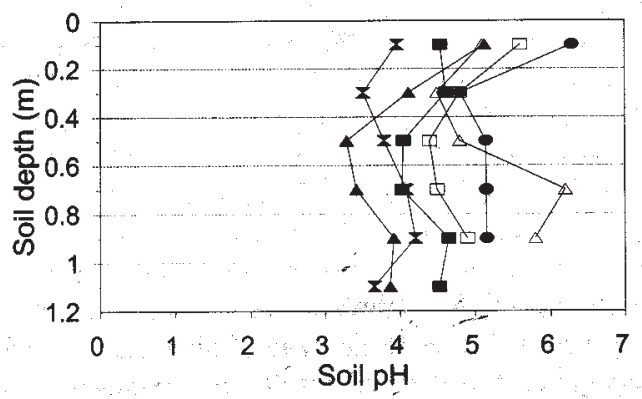

Tweefontein

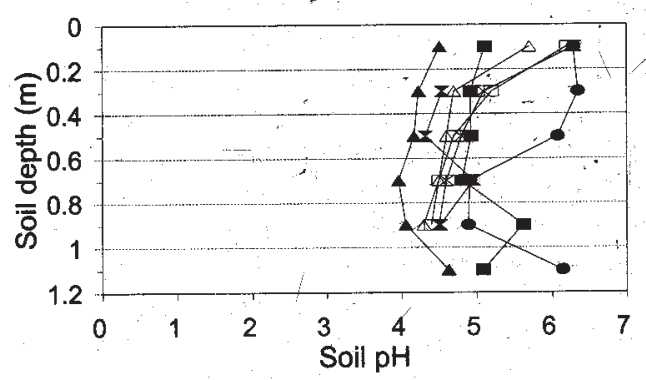

Fourth

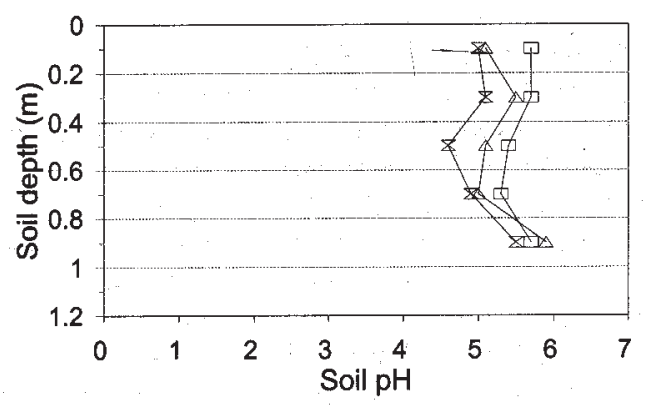

Jacuzzi

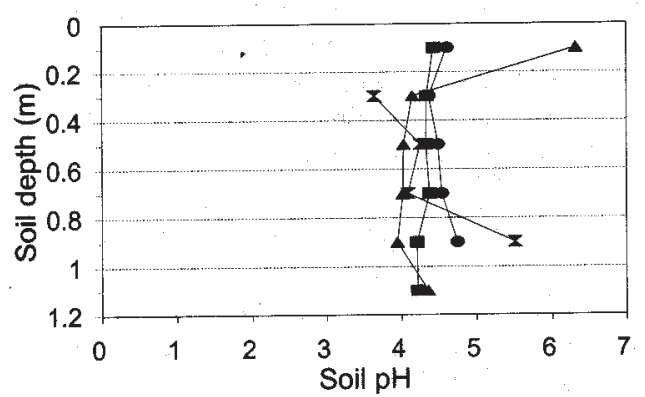

Figure 2

Soil $\mathrm{pH}\left(\mathrm{H}_{2} \mathrm{O}\right)$ as a function of depth and time at four pivot sites for the field capacity treatments
- January 1998
X April 1998
- January 1999
$\square$ July 1999
$\Delta$ July 1998
$\triangle$ December 2000
$\triangle$ January 2000

values of exchangeable $\mathrm{Na}^{+}$were measured during the course of the trial. The detailed results of soluble and exchangeable ion concentrations were reported by Annandale et al. (2001).

The results of the deep-soil sampling, carried out in June 2000, are summarised in Fig. 4. The measurements of saturated soil EC taken in each treatment were compared to those taken in the non-
Leaching fraction treatment

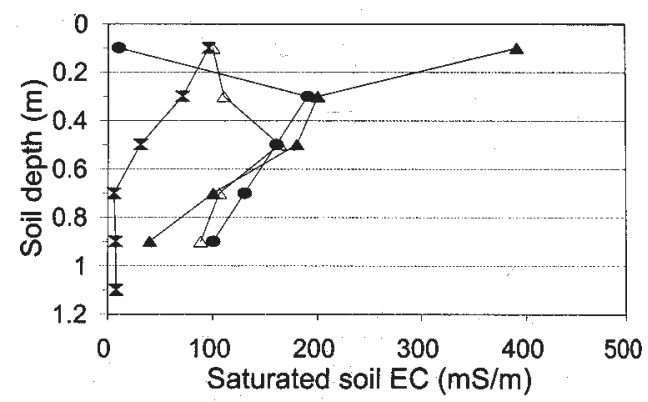

Field capacity treatment

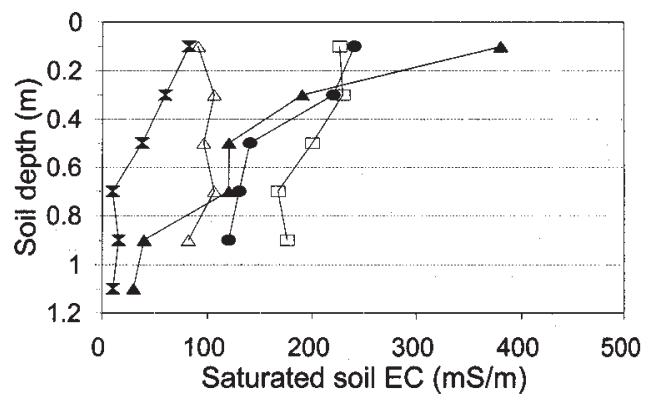

Deficit treatment

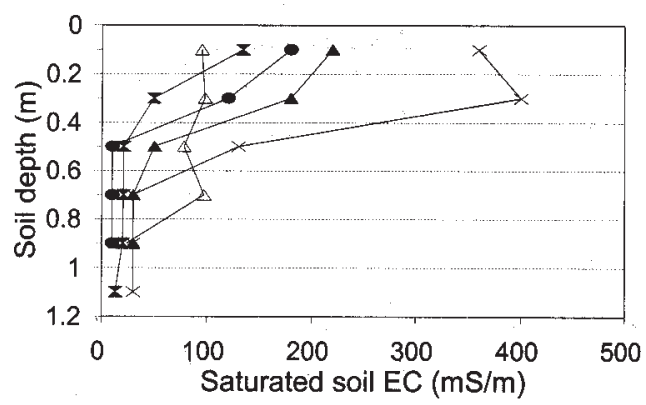

Figure 3

Electrical conductivity of the saturated soil extract $(E C)$ as a function of depth and time at pivot Major for three irrigation treatments

X April $1998 \quad$ A July $1998 \quad$ X October 1998

- January $1999 \quad \square$ July $1999 \quad \triangle$ December 2000

irrigated area outside the pivot. At pivot Major, most soluble salts applied through irrigation water were confined to the upper $1 \mathrm{~m}$, probably due to the presence of the plinthic layer at $1.1 \mathrm{~m}$, which was limiting free drainage. At pivot Fourth, there was a more uniform distribution of salts in the soil profile, with a slight peak between 1.5 and $2 \mathrm{~m}$ down in the profile indicating leaching of salts below the root-zone. The deep-soil sampling at pivot Tweefontein included a sample in the spoil material (deepest data points in Fig. 4).

\section{Groundwater contamination}

The initial water levels in the boreholes ranged from 2.5 to $4.8 \mathrm{~m}$ below the surface. Borehole 5 (BH5, Fig. 1a) was the exception, with a water level depth of $7 \mathrm{~m}$. This was explained by the higher local transmissivity of the aquifer $\left(0.83 \mathrm{~m}^{2} \cdot \mathrm{d}^{-1}\right)$, and thus the greater ability to drain water from this point along the South-West hydraulic 


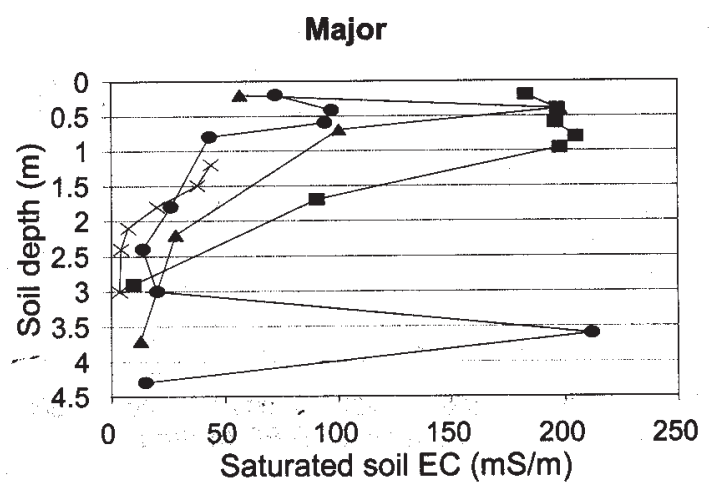

Fourth

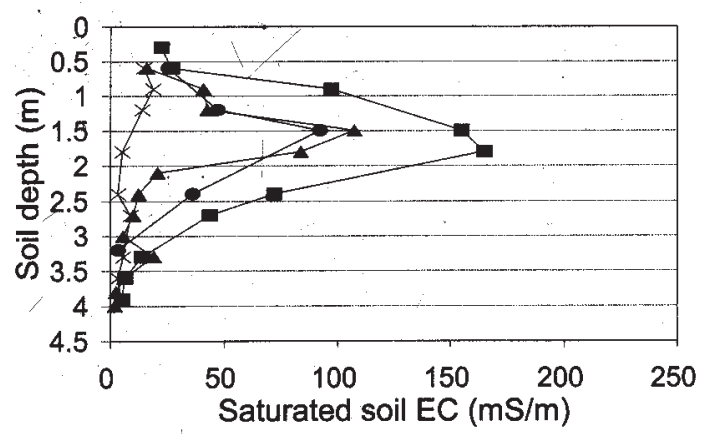

Tweefontein

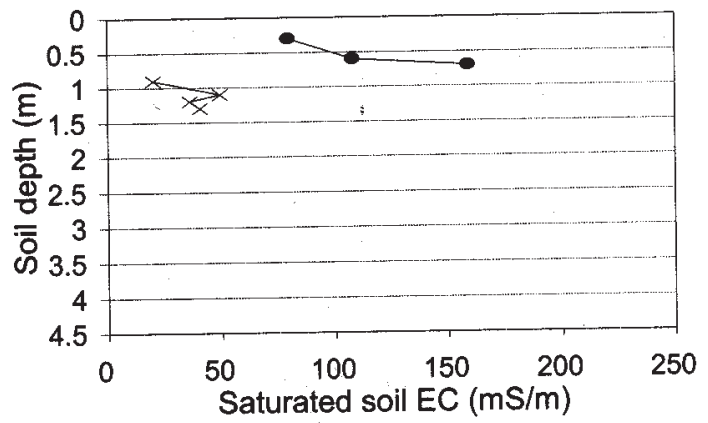

Figure 4

Electrical conductivity of the saturated soil extract (EC) as a function of depth at three pivots (results of the deep-soil sampling carried out in June 2000)

- Leaching fraction treatment - Field capacity treatment

- Deficit treatment $\quad$ X Outside pivot

gradient (Fig. 1a). Due to seasonal fluctuations, water levels in the boreholes rose by approximately $1 \mathrm{~m}$ during summer, which represents approximately $30000 \mathrm{~m}^{3}$ or $100 \mathrm{~mm}$ of water reaching the water table in the irrigation area. This is about $7 \%$ of the average crop water demand for two crops per annum, significantly more than the $6500 \mathrm{~m}^{3}$ that are estimated to be naturally replenished from rainfall at a recharge rate of $3 \%$ per annum. BH5 showed an abnormal rise in its water level over the first 18 months of irrigation, where a consistent rise of $1.5 \mathrm{~m}$ was observed. The initial rise in the water level at this borehole also suggested that more water reached the water table than in the past, before irrigation.

Relevant results of the chemical analyses obtained on samples collected in the boreholes are presented in Fig. 5. The $\mathrm{pH}$ values did not show any particular trend during the period considered. $\mathrm{BH} 2$ and $\mathrm{BH} 8$ showed an increase in nitrate concentrations. Nitrate was the most mobile constituent available in the irrigated system and was derived from fertiliser and/or mineralisation. The mine water did not contain nitrate concentrations at these levels. $\mathrm{BH} 2, \mathrm{BH} 3$, BH5, BH8 and BH9 showed a general but small increase in absolute values of $\mathrm{EC}, \mathrm{Ca}^{2+}, \mathrm{Mg}^{2+}$ and $\mathrm{SO}_{4}{ }^{2-}$. $\mathrm{BH} 4, \mathrm{BH} 6$ and $\mathrm{BH} 7$ showed no increase in any of the constituents. These response patterns are typical of what can be expected in the geological environment of the study areas. Water from the irrigated area will infiltrate along preferred pathways, thus contaminating the aquifer in a patchy manner. The concentrations of other ions in groundwater were negligible. The detailed results of groundwater analyses obtained on samples collected in the boreholes were reported by Annandale et al. (2001).

The limited groundwater contamination measured during the trial confirms the hypothesis of Annandale et al. (1999a), who used the SWB model to predict the salt balance over fifty years of irrigation with water of similar composition as the waters used in this trial. Model predictions indicated that, with appropriate management of gypsiferous water for irrigation, for example deficit irrigations leaving room for rain to replenish the soil profile, considerable masses of salts could be precipitated in the root-zone in the form of gypsum thereby limiting salt leaching and groundwater contamination. The system, however, will have to be monitored over a longer period to confirm these findings.

\section{Conclusions}

In the field trial carried out at Kleinkopje Colliery, several crops were successfully irrigated on a commercial scale with two gypsiferous mine waters of similar composition. Excellent yields were obtained for wheat on both unmined and rehabilitated mined land, and also short-season maize grown on unmined land. The yields of sugar-beans were reasonable, and definitely higher than under dry-land cropping. Problems that caused yield reductions were not related to irrigation with gypsiferous mine water and could be overcome by gaining experience with the management of the specific system. For example, proper preparation of rehabilitated land proved to be important. Subsidence of rehabilitated land caused ponding and waterlogging that had to be overcome by contouring and building drainage waterways. In the rehabilitation process, the spoil material should be shaped to provide a gentle slope to allow lateral flow and prevent ponding that occurs in level areas, if rehabilitated mined land is to be used for crop production under irrigation.

Soil chemical analyses indicated that soil salinity increased over the duration of the trial. Electrical conductivity of the saturated soil extract increased mainly due to an increase in concentrations of soluble $\mathrm{Ca}^{2+}, \mathrm{Mg}^{2+}$ and $\mathrm{SO}_{4}^{2-}$, which were the main ionic species in the irrigation water. Saturated soil EC did not reach values critical to yields of most crops, and decreased after rainy periods. It was also evident that naturally acid soils could be reclaimed through irrigation with water rich in $\mathrm{Ca}^{2+}$. Monitoring of crop nutrient status and careful fertilisation management are indispensable as $\mathrm{Ca}^{2+}$ and $\mathrm{Mg}^{2+}$ dominate the soil-exchange complex with the risk of $\mathrm{K}^{+}$displacement and leaching.

Deep-soil sampling data, as well as groundwater quality data obtained from boreholes indicated that most of the salts applied after three years of irrigation with gypsiferous mine water, were still trapped in the soil and vadose zone. The system, however, will have to be observed over a longer period before a more confident answer can be given in terms of the potential long-term impact of irrigation on the aquifer. Runoff saline water, salt-contaminated 

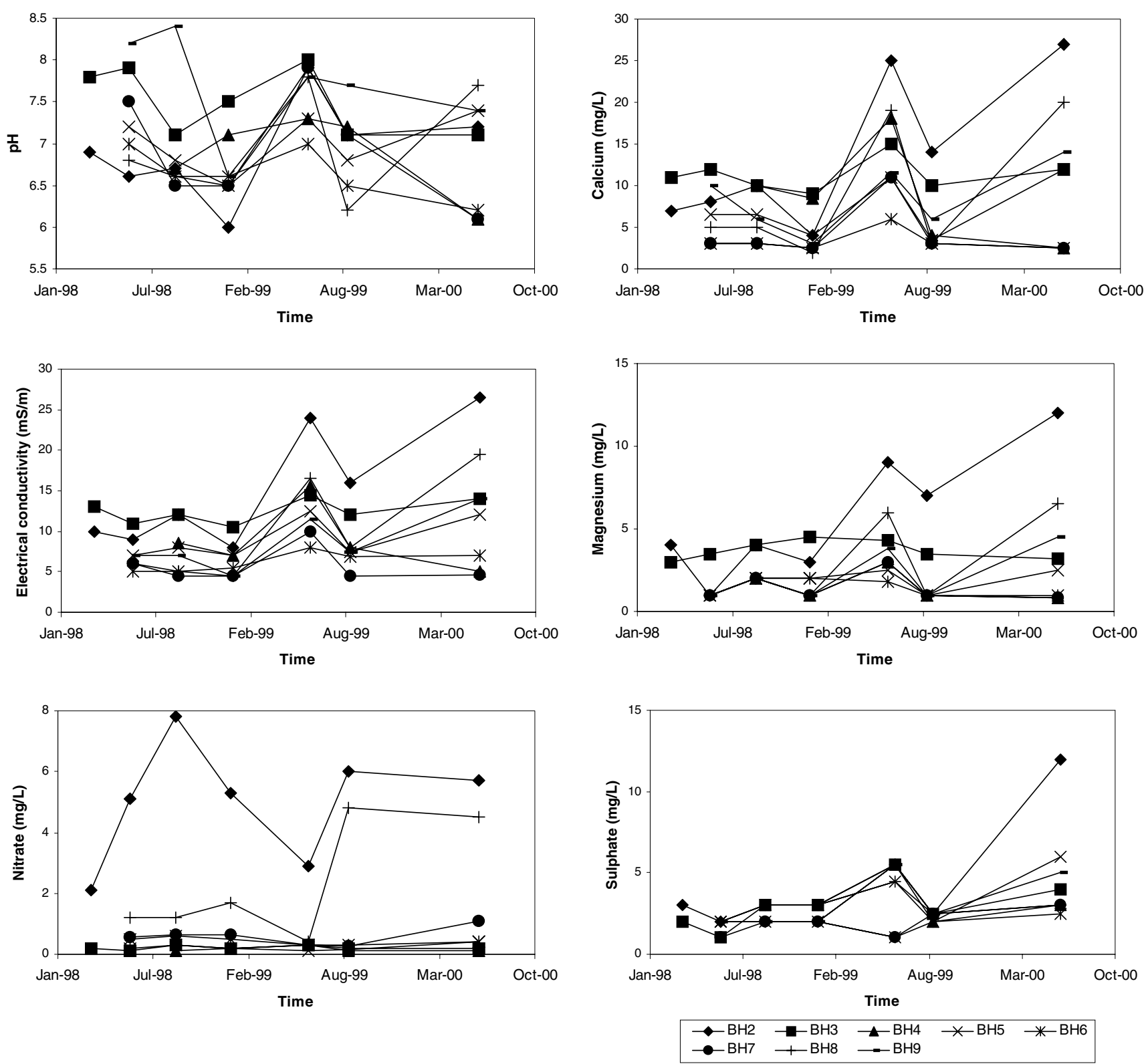

Figure 5

$\mathrm{pH}$, electrical conductivity as well as concentrations of $\mathrm{NO}_{3}{ }^{-}, \mathrm{Ca}^{2+}, \mathrm{Mg}^{2+}$ and $\mathrm{SO}_{4}{ }^{2-}$ measured in eight boreholes (BH) at pivot Major

water moving laterally through the soil along the plinthic or spoil layers, as well as salt-contaminated groundwater could be intercepted and recycled, or used to irrigate a more salt-tolerant crop.

This study has been extended for a further three years to include a wider range of water qualities, soils, climates and cropping systems. The fact that only gypsum can be held up in the soil to some extent, and all other more soluble salts must be leached for successful crop production, suggests that although this technology could make an enormous contribution to water management in the mining industry, it will not be able to completely solve all their salt disposal problems. Some mines also generate significant volumes of saline water that are not particularly gypsiferous. In order to deal with such waters and the concentrated leachate from gypsiferous mine-water irrigation, other agricultural technologies should be considered. The most promising technology is serial biological concentration, where increasingly concentrated leachate from irrigation is intercepted and applied sequentially to increasingly salt-tolerant crops to reduce the volumes of mine water to be desalinised.

\section{Acknowledgements}

The authors acknowledge funding by the Water Research Commission, the Technology and Human Resources for Industry Programme (THRIP, a partnership programme funded by the Department of Trade and Industry and managed by the National Research Foundation), and the industries (Anglo Coal, Sasol, Duiker, Ingwe). Kleinkopje Colliery (Witbank) funded and installed the irrigation system, prepared the land at the experimental site and supplied irrigation water quality data. Two farming companies, Amfarms and Smit Bros., managed commercial production of crops in the field trial. 


\section{References}

ANNANDALE JG, JOVANOVIC NZ, BENADÉ N and TANNER PD (1999a) Modelling the long-term effect of irrigation with gypsiferous water on soil and water resources. Agric. Ecosyst. and Environ. 76109 119.

ANNANDALE JG, BENADÉ N, JOVANOVIC NZ, STEYN JM and DU SAUTOY N (1999b) Facilitating Irrigation Scheduling by Means of the Soil Water Balance Model. Water Research Commission Report No. 753/1/99, Pretoria, South Africa. 285 pp.

ANNANDALE JG, JOVANOVIC NZ, CLAASSENS AS, BENADÉ N, LORENTZ SA, JOHNSTON MA, TANNER PD, AKEN ME, HODGSON FDI (2001) The Influence of Irrigation with Gypsiferous Mine Water on Soil Properties and Drainage Water. Water Research Commission Report No. K5/858, Pretoria, South Africa.

BARNARD RO, RETHMAN NFG, ANNANDALE JG, MENTZ W and JOVANOVIC NZ (1998) The Screening of Crop, Pasture and Wetland Species for Tolerance of Polluted Water Originating in Coal Mines. Water Research Commission Report No. 582/1/98, Pretoria, South Africa. $337 \mathrm{pp}$.

CAMPBELL GS (1990) CLIMGEN, a program that generates weather data (precipitation, maximum and minimum temperature). Unpublished.

DEPARTMENT OF WATER AFFAIRS AND FORESTRY (1993) South African Water Quality Guidelines. Volume 4. Agricultural Water Use. $286 \mathrm{pp}$.
DU PLESSIS HM (1983) Using lime treated acid mine water for irrigation. Water Sci. Technol. 15 145-154.

FAGERIA NK, BALIGAR VC and JONES CA (1991) Growth and Mineral Nutrition of Field Crops. M. Dekker, New York. 150 pp.

JOVANOVIC NZ, BARNARD RO, RETHMANNFG and ANNANDALE JG (1998) Crops can be irrigated with lime-treated acid mine drainage. Water SA 24 (2) 113-122.

KATYAL JC and RANDHAWA NS (1983) Micronutrients. Fert. Irrig. Bull. No. 7. FAO, Rome, Italy. 81-82.

MAAS EV (1986) Salt tolerance in plants. Appl. Agric. Res. 1 (1) 12-26.

PLANK CO (1989) Plant Analysis Handbook for Georgia. University of Georgia Cooperative Extension Service, Athens, Georgia, USA, 37-38.

PULLES W, HOWIE D, OTTO D and EASTON J (1995) A Manual on Mine Water Treatment and Management in South Africa. Water Research Commission Report No. TT 80/96, Pretoria, South Africa.

PULLES W, HEATH R and HOWARD M (1996) A Manual to Assess and Manage the Impact of Gold Mining Operations on the Surface Water Environment. Water Research Commission Report No. TT 79/96, Pretoria, South Africa.

SOIL CLASSIFICATION WORKING GROUP(1991)Soil Classification. A Taxonomic System for South Africa. Dept. of Agricultural Development, Pretoria, South Africa. 262 pp. 
